\title{
Erratum to: PCBs and Organochlorine Pesticides in Ducks of Fereydoon-kenar Wildlife Refuge in Iran
}

\author{
Fateme Rajaei · Nader Bahramifar • \\ Abbas Esmaili Sari · Seyed Mahmoud Ghasempouri • \\ Mozhgan Savabieasfahani
}

Published online: 18 November 2010

(C) Springer Science+Business Media, LLC 2010

Erratum to: Bull Environ Contam Toxicol (2010) 84:577-581

DOI 10.1007/s00128-010-9988-x

Unfortunately, the author Mozhgan Savabieasfahani's name was omitted in the original publication of the article. The missing author's name and the correct order of the authors are provided below.

Rajaei F, Bahramifar N, Esmaili Sari A, Ghasempouri SM, Savabieasfahani M, 2010, PCBs and organochlorine pesticides in ducks of Fereydoon-kenar wildlife refuge in Iran. Bull Environ Contam Toxicol 84(5):577-581.

The online version of the original article can be found under doi:10.1007/s00128-010-9988-x.

F. Rajaei · N. Bahramifar ( $\square)$ · A. E. Sari · S. M. Ghasempouri Department of Environmental Sciences, Faculty of Natural Resources and Marine Sciences, Tarbiat Modares University, P.O. Box 46414-356, Noor, Māzandarān, Iran

e-mail: nbahramifar@yahoo.com

N. Bahramifar

Sari Unit, Department of Chemistry, Payame Noor University (PNU), Māzandarān, Iran

M. Savabieasfahani

Pediatric Endocrinology, University of Michigan, Ann Arbor, MI, USA 